\title{
Studi Pengaruh Penambahan PVA dan Bentonit Terhadap Morfologi dan Sifat Fisik Komposit Berbasis Hidrogel Alginat sebagai Kandidat Material Perancah untuk Regenarasi Tulang Rawan
}

\author{
Amaliya Rasyida, Thalyta Rizkha Pradipta, Sigit Tri Wicaksono \\ Departemen Teknik Material, Fakultas Teknologi Industri \\ Institut Teknologi Sepuluh Nopember (ITS) \\ e-mail: amaliya@mat-eng.its.ac.id / amaliyarasyida@gmail.com
}

\begin{abstract}
Abstrak-Pemanfaatan rumput laut cokelat khususnya didaerah Madura dimana lokasinya yang dekat dengan Surabaya, hanya sebatas untuk makanan warga sekitar. Hal ini menjadi acuan untuk mengembangkan dan meningkatkan potensi rumput laut cokelat dengan mengekstrak salah satu kandungannya yaitu alginat untuk dikembangkan ke arah biomedis khususnya material perancah (scaffold). Dikarenakan keterbatasan sifat fisik dan mekaniknya, maka mulai dikembangkan hidrogel alginat dengan penambahan beberapa material untuk meningkatkan sifat tersebut. Dalam penelitian ini akan dianalisa pengaruh penambahan PVA dan bentonit terhadap morfologi dan sifat fisik komposit berbasis hidrogel alginat serta menganilisis fisibilitas alginat hasil ekstraksi. Sintesis komposit hidrogel alginat/PVA/bentonit dimulai dengan pengekstrasian sodium alginat dari Sargassum sp. asal Sumenep, Madura melalui jalur $\mathrm{CaCl} 2$ kemudian dilanjutkan dengan pembuatan hidrogel alginat. Pembuatan komposit hidrogel alginat/PVA/bentonit ini dengan tambahan PVA dan bentonit sebanyak $5 \%, 10 \%, 15 \%, 20 \%, 25 \%$, dan $30 \%$ wt dari masing-masing bahan ke hidrogel alginat dengan pelarut aquades. Sampel kemudian diuji menggunakan XRF, FTIR, XRD, SEM, viscosity bath, dan hydrolitic degradation. Dari pengujian diatas didapatkan komposisi optimum untuk komposit adalah 70A/15B/15P dan sodium alginat ekstraksi memiliki fisibilitas yang baik untuk dijadikan alternatif pengganti sodium alginat komersil sebagai material perancah. Modifikasi alginat ini diharapkan dapat menjadi kandidat material perancah (scaffold) tulang rawan yang mempunyai sifat biokompatibilitas dan biodegradibilitas yang baik. Selain itu, penelitian ini juga menjadi dasar untuk pemanfaatan hasil ekstraksi bahan alam yang kedepannya dapat dimanfaatkan sebagai bioink pada proses manufaktur $3 \mathrm{D}$ printed.
\end{abstract}

Kata Kunci-Alginat, PVA, Bentonit, Hidrogel, Scaffold.

\section{PENDAHULUAN}

$\mathrm{R}$ umput laut coklat merupakan salah satu sumber daya alam laut yang keberadaannya sangat melimpah dan tumbuh secara alami di perairan pantai Indonesia khususnya di perairan Madura dan Banten, namun potensi ini belum dimanfaatkan secara optimal [1]. Pada umumnya rumput laut coklat mengandung agar-agar, alginat dan karagenan [2] yang digunakan sebagai bahan baku dalam industri makanan, kosmetik dan farmasi [3]. Pemanfaatan rumput laut cokelat khususnya didaerah Madura karena lokasinya yang dekat dengan Surabaya, Jawa Timur, hanya sebatas untuk makanan warga sekitar. Hal inilah yang menjadi acuan untuk mengembangkan dan meningkatkan potensi rumput laut cokelat dengan mengekstrak salah satu kandungannya yaitu alginat untuk dikembangkan ke arah biomedis khususnya material perancah (scaffold). Di alam, ketersediaan rumput laut penghasil alginat selalu ada sepanjang tahun, Oleh karena itu potensi pemanfaatan rumput laut tersebut untuk menghasilkan alginat yang murah dan comparable masih terbuka luas [4]. Alginat merupakan suatu polisakarida hasil ekstraksi rumput laut coklat seperti Sargassum sp. [5]. Salah satu cara yang dapat dilakukan dan dikembangkan yaitu pengekstrasian. Alginat dapat diekstrak dan dimurnikan melalui beberapa jalur seperti jalur ethanol, $\mathrm{HCl}$, dan $\mathrm{CaCl} 2$ [6].

Alginat telah banyak diaplikasikan dalam bidang ilmu biomaterial sebagai bahan baku di bidang medis seperti pembalut luka (wound dressing) [7], bungkus kapsul / obat (delivery drug) [8] dan saat ini banyak peneliti gencar memodifikasi alginat dengan beberapa bahan sebagai pembuat material perancah (scaffold) [9]. Salah satu aplikasi penggunaan tissue engineering adalah dengan pembuatan scaffold yang berfungsi sebagai tempat untuk regenerasi pertumbuhan sel dan jaringan tulang yang baru. Untuk regenerasi jaringan yang berhasil, prasyarat dari scaffold meliputi struktur 3D, berpori, biodegradable, biresorbsi dan mempunyai kekuatan mekanik, serta masih banyak lagi [10]. Beberapa penelitian telah memodifikasi hidrogel alginat dengan bentonit sebagai drug delivery [11], alginat dengan PVA sebagai 3D Printing scaffold [12], alginat dengan PVA dan grafena sebagai scaffold kontruksi rekayasa saraf [9], dan hidrogel alginat dengan hialuronat sebagai cartilage scaffold [13].

Sebelumnya scaffold dibuat dengan bahan biodegradable termasuk polyvinil alkohol (PVA), poli-kaprolakton (PCL), asam polylactic (PLA), asam poliglikolat (PGA), dan polylactic-co-glycolic asam (PLGA) [14]. Namun, kekuatan tekan dan modulus young dari bahan ini tidak mirip dengan jaringan hidup dan beberapa bahan ini sering perlu dilarutkan dengan pelarut yang sangat beracun [15]. Untuk menghindari kekurangan tersebut, dilakukanlah modifikasi dimana polimer alam menawarkan keuntungan yaitu biokompatibel, biodegradabilitas, dan toksisitas rendah sedangkan polimer sintetis memiliki karakteristik yang mudah berubah, mampu dicetak dalam berbagai ukuran dan memiliki sifat mekanik serta tahan panas yang lebih baik. Campuran polimer alami dan sintetis yang disebut sebagai bahan polimer bioartificial 
(biosintesis) dianggap sebagai produk polimer baru yang memperoleh perhatian luar biasa untuk aplikasi biomedis sejak dekade terakhir karena sifat mekanik dan termal serta biokompatibilitas yang dapat ditingkatkan dibandingkan dengan polimer tunggal [16].

Oleh karena itu pada penelitian ini dilakukan sintesis dan karakterisasi komposit hidrogel alginat/polyvinilalkohol (PVA)/bentonit sebagai kandidat material perancah tulang rawan yang kedepannya hasil dari modifikasi material tersebut dapat dimanufaktur menggunakan 3D Printed. Ketiga bahan tersebut memiliki sifat larut dalam air, tidak beracun (non toxic), biokompatibel, dan polimer biodegradable untuk pembuatan scaffold. Hal yang membedakan ialah alginat mudah didapat [5], dan kemampuan gelling yang tinggi [17], sedangkan polyvinil alkohol memiliki tingkat porositas yang tinggi [18], dan bentonit berkemampuan menyerap air yang tinggi [11]. Di antara berbagai kandidat biomaterial, hidrogel semakin banyak dimanfaatkan untuk pengembangan scaffold dikarenakan biokompatibilitas, dan sifat fisik yang dapat diatur [19]. Penelitian ini bertujuan untuk menganalisis pengaruh penambahan PVA dan bentonit terhadap morfologi dan sifat fisik pada komposit berbasis hydrogel alginat serta menganalisis fisibilitas alginat hasil ekstraksi jika dibandingkan dengan alginat komersil pada komposit berbasis hydrogel alginat sebagai kandidat material perancah untuk regenerasi tulang rawan. Perbedaan karakteristik alginate hasil ekstraksi dan komersil telah disampaikan pada penelitian sebelumnya [20].

\section{METODOLOGI PENELITIAN}

\section{A. Proses Ekstraksi Sodium Alginat}

Ekstraksi alginat dari Sargassum sp. dilakukan dengan cara membuat larutan dengan mencampur aquades $400 \mathrm{ml}+0.1$ $\mathrm{M} \mathrm{HCl}$ (dengan cara diteteskan) hingga larutan tersebut mempunyai pH 4. Selanjutnya serbuk Sargassum sp. 10 gram dilembabkan dengan menggunakan larutan $\mathrm{HCl}$ sebanyak $100 \mathrm{ml}$ diaduk menggunakan magnetic stirrer selama 15 menit dengan temperatur $27^{\circ} \mathrm{C}$. Diulang sebanyak 3 kali. Hasil disaring, yang diambil adalah serbuk sargassum yang telah lembab. Serbuk sargassum yang telah lembab diletakkan di beaker dengan penambahan $1 \mathrm{M} \mathrm{Na}_{2} \mathrm{CO}_{3}$ sebanyak $250 \mathrm{ml}$ dengan $\mathrm{pH}$ 11,5. Kemudian diaduk menggunakan magnetic stirrer dengan temperatur 60oC selama 2 jam kecepatan 350 rpm. Selanjutnya disaring, yang digunakan adalah hasil larutannya. Hasil larutan tersebut diencerkan kembali dengan $800 \mathrm{ml}$ aquades ditambah 1 gram diatomaceous earth lalu diaduk 15 menit menggunakan magnetic stirrer dengan kecepatan 450 rpm. Larutan tersebut selanjutnya dipisahkan dengan pendiaman selama sehari lalu disaring dengan menggunakan kertas saring dan material yang terpisahkan berupa pasta (sodium alginat) dan larutan (aquades).

\section{B. Proses Pemurnian Sodium Alginat Jalur $\mathrm{CaCl}_{2}$}

Hasil ekstraksi Sodium Alginat ditambahkan $200 \mathrm{ml} 1 \mathrm{M}$ $\mathrm{CaCl}_{2}$ lalu diaduk biasa dan ditunggu mengendap. Hasil tersebut disaring menggunakan kertas saring dan diambil endapannya. Endapan tadi dimasukkan ke dalam alat pemurnian soxchlet selama 2x24 jam dengan temperature hot plate stirrer $540^{\circ} \mathrm{C}$ dan temperature dalam $\mathrm{H}_{2} \mathrm{O}$ (aquades) $100^{\circ} \mathrm{C}$ dalam keadaan vacuum dan stabil. Selanjutnya, endapan tadi yang telah dikeluarkan dari soxchlet dicampur dengan $150 \mathrm{ml}$ aquades dan $1 \mathrm{M} \mathrm{HCl}$ (ditetesin sampai $\mathrm{pH}$ 2) lalu diaduk dengan menggunakan magnetic stirrer selama 3.5 jam temperature $27^{\circ} \mathrm{C}$. Selanjutnya diendapkan menggunakan centrifuge. Material yang tidak larut dalam proses centrifuge akan mengendap (Alginic Acid). Alginic Acid ini dicuci dengan $1 \mathrm{~L} 0.05 \mathrm{M} \mathrm{HCl}$, diaduk menggunakan magnetic stirrer selama 15 menit dengan temperature $27^{\circ} \mathrm{C}$. Selanjutnya disaring menggunakan kertas saring. Yang digunakan adalah endapannya. Endapan hasil saringan tersebut ditambahkan $100 \mathrm{ml}$ aquades ditambah $150 \mathrm{ml} 1 \mathrm{M}$ $\mathrm{Na}_{2} \mathrm{CO}_{3}$ kemudian diaduk menggunakan magnetic stirrer selama 1 jam dengan temperature $27^{\circ}$ lalu disaring diambil endapannnya. Endapan tersebut dicampur ethanol $1: 1 \mathrm{v} / \mathrm{v}$ secara perlahan lalu disaring menggunakan kertas saring dan yang diambil endapannya. Selanjutnya, endapan terakhir ini dimasukkan ke dalam alat pemurnian soxchlet selama 7 jam dengan temperatur hot plate stirrer $480^{\circ} \mathrm{C}$ dan temperature ethanol $78^{\circ} \mathrm{C}$ dengan keadaan vacuum dan stabil. Lalu dikeringkan endapan tersebut dan dihaluskan sodium alginatnya.

\section{Pembuatan Hidrogel Alginat}

Menyiapkan aquades sebanyak $100 \mathrm{ml}$. Mencampurkan aquades sebanyak $100 \mathrm{ml}$ dengan powder sodium alginat sebanyak 7 gram, diaduk menggunakan hot plate magnetic stirrer selama 2 jam dengan temperatur $120^{\circ} \mathrm{C}$ dan kecepatan pengadukan sebesar $1000 \mathrm{rpm}$.

\section{Pembuatan Komposit Hidrogel Alginat/PVA/Bentonit}

Menyiapkan hidrogel alginat sebanyak kurang lebih 100 ml. Menyiapkan PVA (sesuai \%wt yang dibutuhkan) dan dicampur dengan hidrogel alginat sebanyak $100 \mathrm{ml}$, lalu diaduk dengan magnetic stirrer selama 2 jam dengan temperatur $120^{\circ} \mathrm{C}$ dan kecepatan $1000 \mathrm{rpm}$. Mencampurkan hidrogel alginat/PVA dengan powder bentonit (sesuai \%wt yang dibutuhkan) lalu diaduk dengan magnetic stirrer selama 2 jam dengan temperatur $120^{\circ} \mathrm{C}$ dan kecepatan $1000 \mathrm{rpm}$. Mengeringkan komposit hidrogel alginat/PVA/bentonit pada temperatur ruang $27^{\circ} \mathrm{C}$ selama sehari.

\section{E. Pengujian dan karakterisasi penelitian}

Untuk mengetahui kandungan unsur yang terdapat pada setiap raw material dilakukan pengujian $X$-Ray Fluoroscence (XRF). Bahan yang digunakan berbentuk powder sebanyak kurang lebih 2 gram per sampelnya dengan temperatur kurang lebih $22-27^{\circ} \mathrm{C}$ dan tingkat kelembapan 49\%-53\%. Pengamatan struktur dilakukan dengan menggunakan mesin uji $X$-Ray Diffraction Method (XRD). Setiap sampel yang digunakan berbentuk hidrogel dengan penembakan sudut $2 \theta=5^{\circ}-80^{\circ}$ dan $\lambda \mathrm{Cu}-\mathrm{K} \alpha=1.54060$. Dilakukan pengujian Fourier-Transform Infrared (FTIR) untuk mengetahui gugus fungsi yang terbentuk selama proses sintesa menggunakan instrument Thermo Scientic Nicolet IS10 dengan panjang gelombang $400-4000 \mathrm{~cm}^{-1}$ dan sampel berbentuk hidrogel. Pengamatan morfologi dilakukan dengan menggunakan instrument Scanning Electron Microscope (SEM) Inspect S50 dengan bentuk sampel hidrogel. Sedangkan untuk pengujian viscosity bath dengan jenis pengujian kinematic viscosity. Spesifikasi sampel yaitu cair sedikit kental, dengan jumlah 20-100 ml, dan data yang diperoleh nilai viskositas dengan satuan cSt dengan standart metode pengujian ASTM D 445-97. Untuk pengujian degradasi material menggunakan hydrolitc degradation dengan melakukan perendaman hidrogel di dalam larutan PBS pada temperatur $37^{\circ} \mathrm{C}$ selama 35 hari. Pengukuran berat dilakukan setiap 1 minggu sekali. 
Larutan PBS ditambahkan setiap 1 minggu sekali setelah penimbangan untuk meyakinkan bahwa seluruh sampel terendam dengan sempurna.

$$
\mathrm{W}=(\mathrm{ma}-\mathrm{mb}) / \mathrm{mb}
$$

Dimana ma adalah massa yang terukur setelah perendaman SBF dan mb adalah massa sebelum perendaman.

\section{HASIL DAN PEMBAHASAN}

\section{A. Hasil Pengujian XRD}

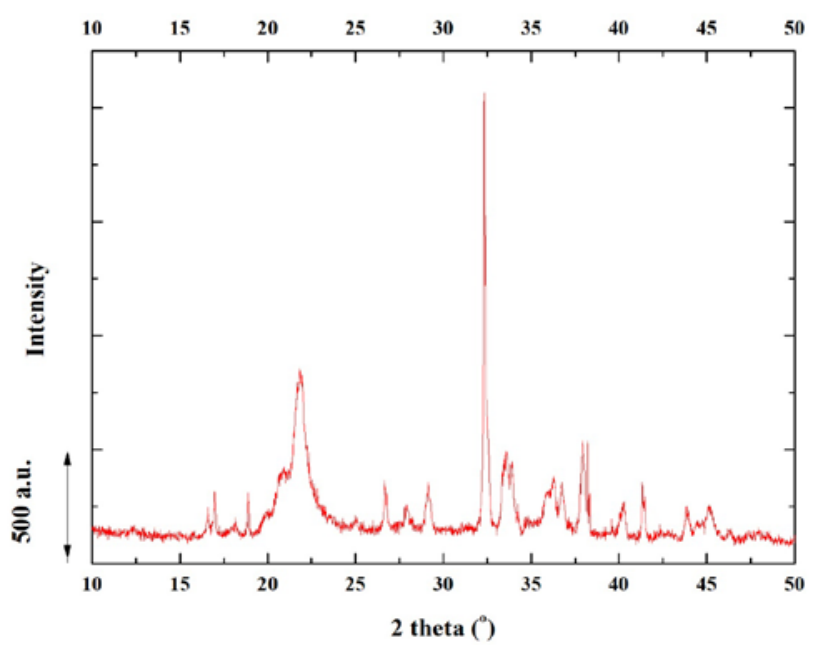

Gambar 1. Difraktogram XRD dari Sampel Sodium Alginat Ekstraksi.

Pola XRD sodium alginat ekstraksi ditunjukkan pada gambar 1. Dapat dilihat bahwa sodium alginat ekstraksi memiliki struktur semi kristalin dengan puncak $2 \theta=19,9^{\circ}$; $21,9^{\circ} ; 26,7^{\circ} ; 29,1^{\circ} ; 32,4^{\circ} ; 33,8^{\circ} ; 38,3^{\circ}$. Dalam penelitian Julia (2014) juga ditemukan bahwa difraktogram XRD pada alginat mempunyai puncak kristalinitas pada $2 \theta=18,7^{\circ}$; $22,2^{\circ} ; 29,2^{\circ} ; 32,5^{\circ} ; 37,1^{\circ}$, dimana peak ini terdapat pada sodium alginat hasil ekstraksi. Indeks kristalinitas dari sodium alginat ekstraksi 35,67 \%.

Gambar 2 menunjukkan pola XRD dari material penyusun dan hasil kompositnya. Untuk PVA memiliki struktur semi kristalin yang ditunjukkan pada puncak $2 \theta=15,6^{\circ} ; 19,3^{\circ}$; $19,7^{\circ} ; 22,6^{\circ} ; 40,5^{\circ}$. Menurut Kannan (2017) struktur semi kristalin PVA dikaitkan dengan fase kristal dari polimer yang dibentuk oleh ikatan hidrogen tinggi antara kelompok hidroksil. Indeks kristalinitas dari PVA adalah 40,99 \%.

Bentonit memiliki struktur semi kristalin dengan $2 \theta=7,1^{\circ}$; 8,$8 ; 13,5^{\circ} ; 20,8^{\circ} ; 22.1^{\circ} ; 22.3^{\circ} ; 25,6^{\circ} ; 26,7^{\circ} ; 27,7^{\circ} ; 30,9^{\circ}$. Hasil ini sesuai dengan pola montmorillonite JCPDS card No. 13-0135. Pola difraksi bentonit memiliki 10 refleksi utama, dan refleksi 001 pertama untuk bentonit sederhana diamati pada (001) d-value $=9,8,2 \theta=9.00^{\circ}$, dan pantulan lainnya pada $\mathrm{d}$-value $=4,4499,2 \theta=19,94^{\circ}, \mathrm{d}$-value $=3,1890$, $2 \theta=27,96^{\circ}$, d-value $=2,9970,2 \theta=29,79^{\circ}, \mathrm{d}$-value $=2,5549$, $2 \theta=35,10^{\circ}$ dan $\mathrm{d}$-value $=1,4952,2 \theta=62,02^{\circ}$, yang mengarakterisasi sampel terutama sebagai montmorillonite [21]. Selain itu, ada refleksi yang terkait dengan kuarsa (dvalue $=4.2557,2 \theta=20.86^{\circ}, \mathrm{d}$-value $=3.3196,2 \theta=26.75^{\circ}$ dan $d$-value $\left.=1.9890,2 \theta=45.60^{\circ}\right)[22]$. Bentonit juga terdiri dari kristobalit $\left(\mathrm{d}\right.$-value $=2.800,2 \theta=31.94^{\circ}$ ) sebagai komponennya [23]. Indeks kristalinitas dari bentonit adalah $69,90 \%$.

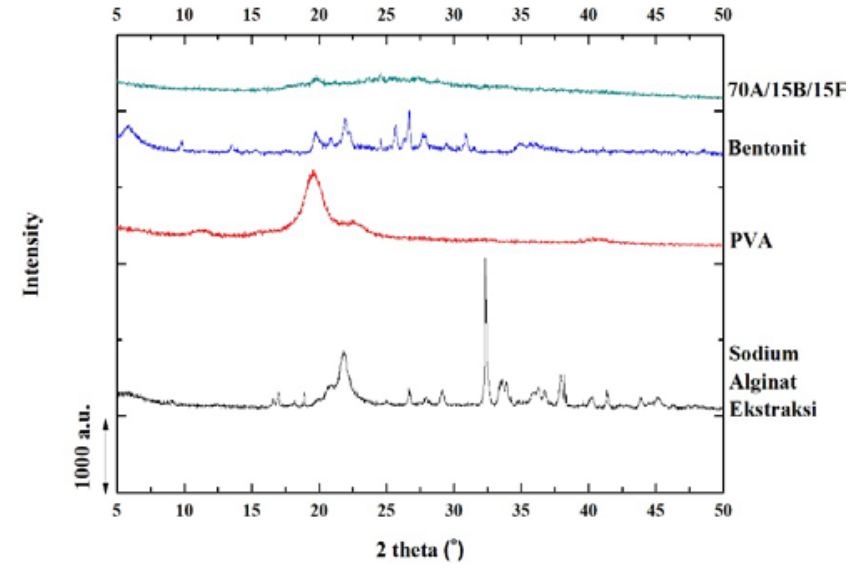

Gambar 2. Perbandingan Grafik XRD dari Sodium Alginat Ekstraksi, PVA Bentonit dan Komposit hidrogel 70A/15B/15P Alginat Ekstraksi

Tabel 1.

Indeks Kristalinitas pada Sampel Komposit Hidrogel Alginat Ekstraksi

\begin{tabular}{ccc}
\hline \hline Komposisi & \% Kristalin & \% Amorfus \\
\hline 70A/30B & 40,74 & 59,26 \\
$70 \mathrm{~A} / 15 \mathrm{~B} / 15 \mathrm{P}$ & 43,06 & 56,94 \\
$70 \mathrm{~A} / 10 \mathrm{~B} / 20 \mathrm{P}$ & 43,60 & 56,32 \\
$70 \mathrm{~A} / 5 \mathrm{~B} / 25 \mathrm{P}$ & 33,84 & 66,16 \\
70A/30P & 39,26 & 60,74 \\
$70 \mathrm{~A} / 20 \mathrm{~B} / 25 \mathrm{P}$ & 44,34 & 55,66 \\
$70 \mathrm{~A} / 25 \mathrm{~B} / 5 \mathrm{P}$ & 43,91 & 56,09 \\
\hline \hline
\end{tabular}

Pada hasil XRD komposit hidrogel 70A/15B/15P alginat ekstraksi puncak $2 \theta=21.8^{\circ} ; 26.5^{\circ} ; 29.4^{\circ} ; 30.8^{\circ} ; 36.1^{\circ}$. Penggabungan struktur dari ketiga penyusunnya diidentifikasi pada puncak difraksi $2 \theta=21.8^{\circ}$ dan $26.5^{\circ}$ yang memiliki struktur semi kristalin dengan indeks kristalinitas sebesar 43,06\%. Pada penelitian sebelumnya [9] menjelaskan puncak difraksi komposit alginat/PVA yang bersifat amorf terletak pada $2 \theta=20.6^{\circ}$.

\section{B. Hasil Pengujian SEM}

Gambar 4 menunjukkan hasil SEM perbesaran 500x pada sampel komposit hidrogel alginat ekstraksi/PVA/bentonit. Karena PVA adalah polimer yang mudah larut dalam air [24] sedangkan alginat dan bentonit adalah polimer hidrofilik dan swelling di air [11], maka ketiganya dapat tercampur seperti terlihat pada gambar 3. Hasil SEM komposit hidrogel alginat ekstraksi menunjukkan adanya tingkat kekasaran yang berbeda dan tidak adanya porositas. Terlihat ketujuh sampel memiliki kekasaran yang hampir sama. Pada penelitian yang dilakukan Seung Taek-Oh (2008) disebutkan dengan adanya penambahan bentonit, tingkat kekasaran dari hydrogel alginat/bentonit meningkat. Sampel 70A/30B alginat ekstraksi bila dibandingkan dengan sampel 70A/30B penelitian Seung Taek-Oh, keduanya memiliki tingkat kekasaran yang hampir sama. 

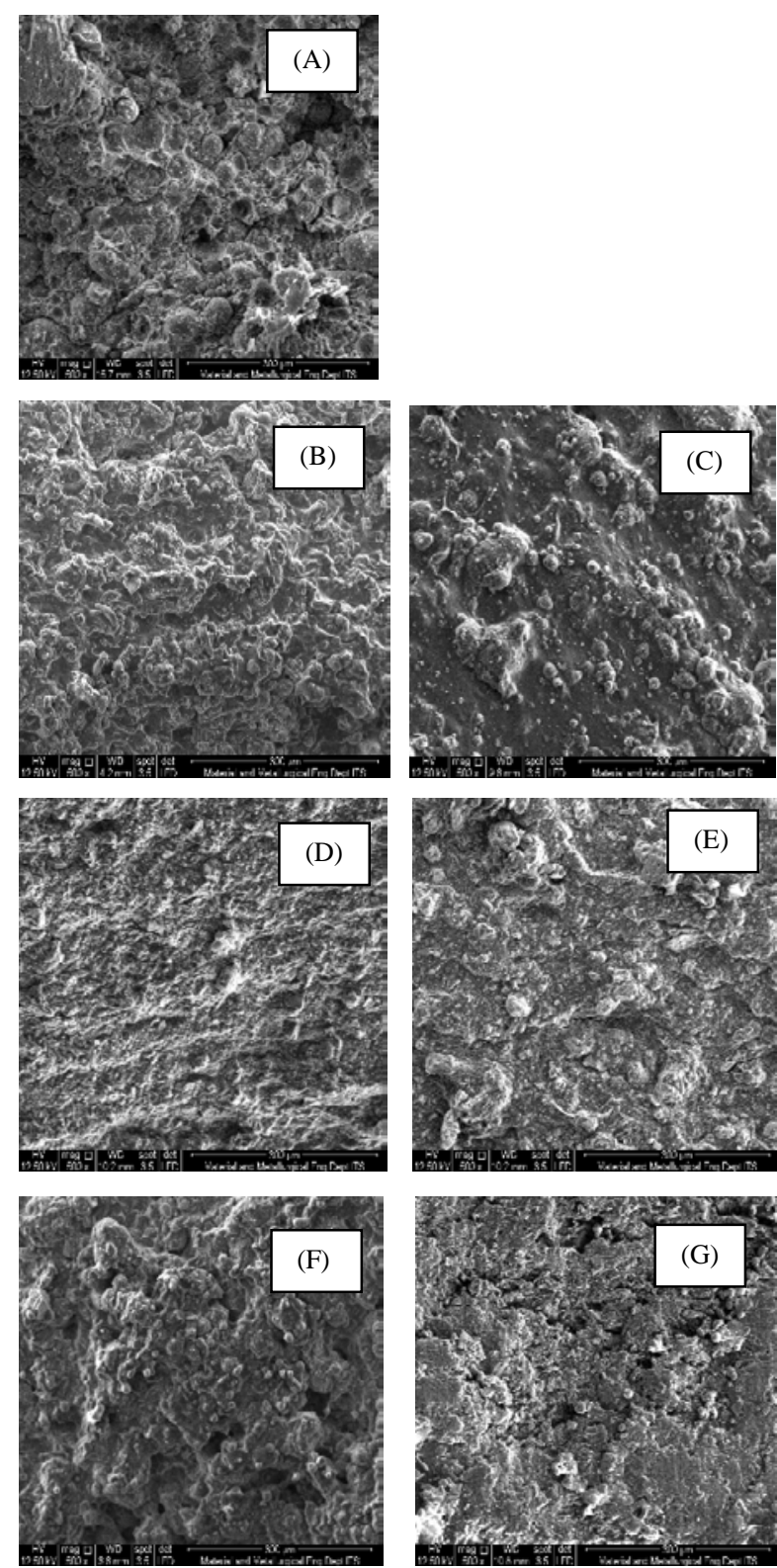

Gambar 3. Hasil SEM perbesaran 500x. Sampel Komposit hidrogel Alginat Ekstraksi/PVA/Bentonit A). 70A/303; B). 70A/15B/15P; C). 70A/10B/20P; D). 70A/5B/25P; E). 70A/30P; F). 70A/20B/10P; G). 70A/25B/5P.

\section{Hasil Pengujian Viscosity Bath}

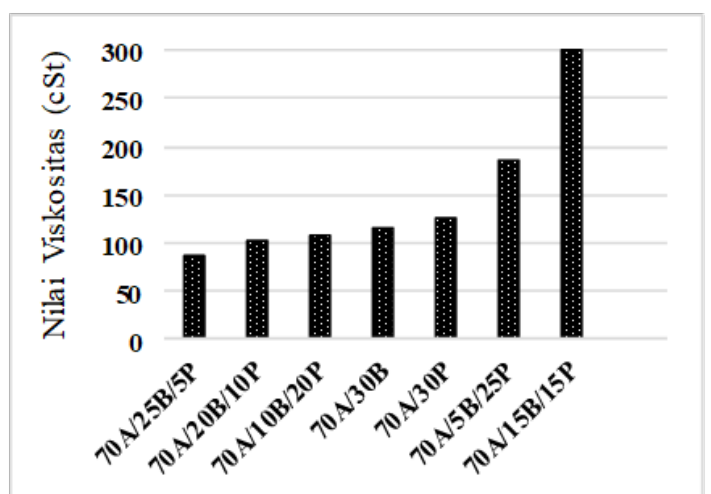

Gambar 4. Perbandingan Nilai Viskositas pada Sampel Komposit hidrogel Alginat Ekstraksi.

Gambar 4 menampilkan nilai viskositas dari masingmasing komposisi komposit hidrogel alginat ekstraksi/PVA/bentonit. Secara keseluruhan, komposit hidrogel alginat ekstraksi memiliki angka viskositas yang tinggi. Hasil ini didukung dengan teori bahwa alginat adalah molekul rantai panjang dengan banyak ion negatif (anion). Pada proses penambahan air, molekul-molekul alginat mengalami pengikatan air [25]. Asam alginat tidak larut dalam air, hanya swelling (mengembang). Alginat yang mengandung kation $\mathrm{Na}^{+}, \mathrm{Ca}^{2+}$, atau $\mathrm{K}^{+}$dapat larut dalam air panas maupun dingin dan membentuk larutan stabil [26]. Jika kita menarik kembali ke awal bahwa sodium alginat ekstraksi mengandung banyak $\mathrm{Na}$ dan $\mathrm{Ca}$ maka dapat diindikasikan untuk sifat kental dari komposit ini dipengaruhi oleh sodium alginat ekstraksi. Sodium alginat (natrium alginat) yang dapat larut, bisa diubah menjadi sebuah hidrogel melalui ikatan silang dengan kation divalen (mis. $\mathrm{Ca}^{2+}$ ) sebagai berikut. Reaksi:

$\mathrm{COOH}+\mathrm{Ca}^{2+}+\mathrm{COOH} \rightarrow \mathrm{COO}-\mathrm{Ca}-\mathrm{COO}+2 \mathrm{H}^{+}$

Kekuatan hydrogel dari PVA juga mempengaruhi sifat kekentalan dari komposit ini. Semakin banyak konsentrasi berat PVA maka akan terbentuk ikatan C-H yang masih berstruktur kristalin [12]. Struktur kristalin inilah yang mempengaruhi tingkat kekentalan dari komposit.

Penggunaan bentonit yang berlebihan dapat menyebabkan menurunnya kemampuan kekentalan komposit, karena penyerapan air bentonit diketahui lebih rendah daripada alginat [11]. Hal ini sesuai dengan hasil sampel 70A/25B/5P yang memiliki tingkat kekentalan yang paling rendah.

Pada gambar 4, terlihat hasil viskositas komposit hidrogel alginat ekstraksi dari yang terendah hingga tertinggi dengan nilai viskositas pada sampel 70A/25B/5P sebesar 85,99 cSt, sampel 70A/20B/10P sebesar 101,46 cSt, sampel 70A/10B/20P sebesar 108,56 cSt, sampel 70A/30B sebesar $115,89 \mathrm{cSt}$, sampel 70A/30P sebesar 126,82 cSt, sampel 70A/5B/25P sebesar 185,73 cSt, dan sampel 70A/15B/15P sebesar 300,08 cSt. Hasil ini diukur dengan tingkat kelembapan $51 \%$ dan temperatur $23^{\circ} \mathrm{C}$. Hasil nilai viskositas tertinggi ditunjukkan oleh sampel yang terdiri dari 70\% wt alginat ekstraksi, 15\% wt bentonit, dan 15\% wt PVA.

Standart viskositas untuk difabrikasi oleh 3D-printed melalui metode extrusion adalah $300 \mathrm{mPa} / \mathrm{s}$ atau diatas $6 \times 10^{7}$ $\mathrm{mPa} / \mathrm{s}$ (Murphy, 2014). Dimana untuk 1 cSt sama dengan 1 $\mathrm{mPa} / \mathrm{s}$. Dengan adanya batasan tersebut, komposit hidrogel alginat ekstraksi dengan komposisi 70A/15B/15P (wt\%) telah memenuhi kriteria sehingga dapat dikandidatkan sebagai salah satu material yang mampu difabrikasi oleh 3D-printed metode extrusion seperti pada gambar 5 .
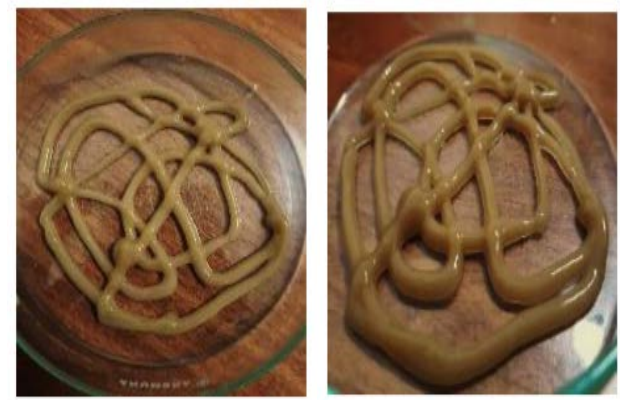

Gambar 5. Perbandingan visualisasi komposit hidrogel alginat ekstraksi 70A/15B/15P melalui fabrikasi pendekatan extrusion 3D-Printed. 


\section{Hasil Pengujian Hydrolitic Degradation}

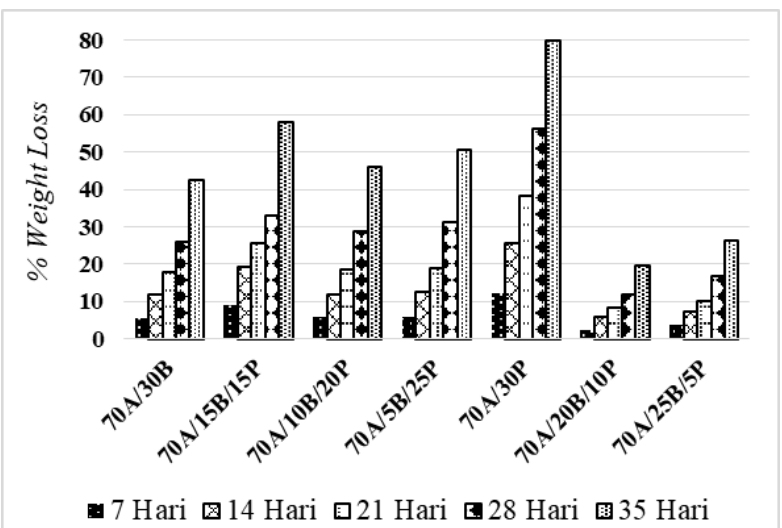

Gambar 6. Perbandingan Hasil Degradasi pada Komposit hidrogel Alginat Ekstraksi selama 35 hari

Pada gambar 6 disebutkan perbandingan hasil degradasi (weight loss) dari ketujuh sampel komposit hidrogel alginat ekstraksi selama 35 hari. Berat awal dari setiap sampel adalah 5 gram. Dari setiap sampel mengalami kenaikan weight loss dari hari ke- 7, 14, 21, dan 35. Sampel yang cepat terdegradasi pada hari ke 35 adalah sampel dengan komposisi 70A/30P dan $70 \mathrm{~A} / 15 \mathrm{~B} / 15 \mathrm{P}$ dengan persen degradasi sebesar $80 \%$ dan $60 \%$. Hal ini dikarenakan dari ketiga bahan tersebut memiliki sifat biodegradasi yang cukup tinggi. Alginat bioinks dalam konsentrasi tinggi sangat dipengaruhi oleh ion kalsium $\left(\mathrm{Ca}^{2+}\right)$. Dalam kondisi basah (seperti pada media kultur sel atau larutan PBS), scaffold alginat akan membengkak karena penyerapan air yang efisien. Keterikatan antara serat alginat yang lemah dan ikatan silang ion kalsium yang lemah akibat perendaman menyebabkan berkurangnya kekakuan scaffold alginat [10].

Pada sampel komposisi 70A/30P, tingkat degradasi yang tinggi disebabkan oleh keberadaan pori-pori mikro yang banyak dimana secara signifikan dapat meningkatkan adsorpsi air, degradasi yang tinggi dan menurunkan sifat mekanik scaffold [12]. Untuk sampel 70A/15B/15P, hal ini dikarenakan adanya bentonit yang merupakan zat tambahan penting dalam produk medis karena sifat penyerapan dan degradasi yang baik [27]. Bentonit adalah bahan anorganik inert, yang tidak dapat didegradasi dengan mudah. Oleh karena itu, biodegradabilitas komposit dapat dikontrol dengan pencampuran jumlah bentonit yang berbeda. Jumlah bentonit yang berlebihan dapat menghasilkan biodegradabilitas yang buruk dan meningkatkan kesulitan dalam pelepasan sel nantinya [28]. Marco (2005) menyebutkan perilaku degradasi perancah (scaffold) harus bervariasi berdasarkan aplikasi seperti 9 bulan atau lebih untuk perancah tulang belakang dan 2-6 bulan untuk perancah dalam aplikasi tulang rawan. Hal ini didukung oleh penelitian Hyun Chung (2006), disebutkan bahwa neocartilage terbentuk setelah kultur in vitro pada perancah selama 12 minggu dimana menunjukkan ciri morfologi dan sifat biomekanis yang mulai lengkap.

\section{KESIMPULAN}

Dengan adanya penambahan bentonit dapat meningkatkan kekasaran pada morfologi komposit hidrogel. Sifat fisik komposit ini ditinjau berdasarkan nilai viskositas dan degradasi material yaitu nilai viskositas yang tinggi didapati oleh komposit sodium alginat ekstraksi dengan komposisi 70A/15B/15P dimana nilai viskositas ini memenuhi kriteria material yang mampu difabrikasi oleh 3D-Printed dengan metode extrusion, sebesar 300,08 mPa/s. Untuk hasil degradasi yang optimal selama 35 hari didapatkan pada komposisi 70A/15B/15P untuk komposit hidrogel alginat ekstraksi dengan \% weight loss nya $60 \%$.

Sodium alginat hasil ekstraksi memiliki fisibilitas yang baik sehingga dapat dijadikan alternatif pengganti untuk sodium alginat komersil sebagai material perancah. Hal ini ditunjukkan dengan memiliki kandungan unsur yang mirip dengan sodium alginat komersil ( $\mathrm{Na}, \mathrm{P}, \mathrm{Ca}, \mathrm{Fe}, \mathrm{Cu}$, dan $\mathrm{Br}$ ), memiliki nilai viskositas yang tinggi pada komposisi 70A/15B/15P, nilai sebesar $300,08 \mathrm{mPa} / \mathrm{s}$, serta memiliki weight loss untuk pengujian degradasi sebesar $60 \%$ pada komposisi 70A/15B/15P dalam waktu 35 hari.

\section{UCAPAN TERIMA KASIH}

Penulis mengucapkan terima kasih kepada Program pendanaan Penelitian Pemula DANA LOKAL ITS tahun 2017.

\section{DAFTAR PUSTAKA}

[1] Y. Y, Teknologi pengolahan alginat. Jakarta: Pusat Riset Pengolahan Produk dan Sosial Ekonomi Kelautan dan Perikanan, Badan Riset Kelautan dan Perikanan, Departemen Kelautan dan Perikanan, 2004.

[2] H. J. Bixler and H. Porse, "A decade of change in the seaweed hydrocolloids industry,” J. Appl. Phycol., vol. 23, no. 3, pp. 321-335, Jun. 2011.

[3] N. I. Gerasimenko, N. G. Busarova, and O. P. Moiseenko, "Seasonal changes in the content of lipids, fatty acids, and pigments in brown alga Costaria costata,” Russ. J. Plant Physiol., vol. 57, no. 2, pp. 205 211, Mar. 2010.

[4] W. S. Atmadja, Pengenalan jenis-jenis rumput laut Indonesia. Jakarta: Puslitbang Oseanologi LIPI, 1996.

[5] S. Limpanuphap and B. Derby, "Manufacture of biomaterials by a novel printing process,” J. Mater. Sci. Mater. Med., vol. 13, no. 12 pp. 1163-1166, 2002.

[6] C. G. Gomez, M. V. Pérez Lambrecht, J. E. Lozano, M. Rinaudo, and M. A. Villar, "Influence of the extraction-purification conditions on final properties of alginates obtained from brown algae (Macrocystis pyrifera),” Int. J. Biol. Macromol., vol. 44, no. 4, pp. 365-371, May 2009.

[7] T. Mutia, R. Eriningsih, and R. Safitri, "Membran alginat sebaga pembalut luka primer dan media penyampaian obat topikal untuk luka yang terinfeksi,” J. Ind. Res. (Jurnal Ris. Ind., vol. 5, no. 2, pp. 161174, Apr. 2011.

[8] H. Anwar, M. Ahmad, M. U. Minhas, and S. Rehmani, “Alginatepolyvinyl alcohol based interpenetrating polymer network for prolonged drug therapy, Optimization and in-vitro characterization," Carbohydr. Polym., vol. 166, pp. 183-194, Jun. 2017.

[9] N. Golafshan, M. Kharaziha, and M. Fathi, "Tough and conductive hybrid graphene-PVA: Alginate fibrous scaffolds for engineering neural construct,” Carbon N. Y., vol. 111, pp. 752-763, Jan. 2017.

[10] M. Ye, P. Mohanty, and G. Ghosh, "Morphology and properties of poly vinyl alcohol (PVA) scaffolds: Impact of process variables," Mater. Sci. Eng. C, vol. 42, pp. 289-294, Sep. 2014.

[11] S.-T. Oh, O.-J. Kwon, B.-C. Chun, J.-W. Cho, and J.-S. Park, “The effect of bentonite concentration on the drug delivery efficacy of a pH-sensitive alginate/bentonite hydrogel," Fibers Polym., vol. 10, no. 1, pp. 21-26, Feb. 2009.

[12] Y. Luo, G. Luo, M. Gelinsky, P. Huang, and C. Ruan, “3D bioprinting scaffold using alginate/polyvinyl alcohol bioinks,” Mater. Lett., vol. 189, pp. 295-298, Feb. 2017.

[13] H. Park, H. J. Lee, H. An, and K. Y. Lee, “Alginate hydrogels modified with low molecular weight hyaluronate for cartilage regeneration,” Carbohydr. Polym., vol. 162, pp. 100-107, Apr. 2017.

[14] L. S. Nair and C. T. Laurencin, "Biodegradable polymers as biomaterials,” Prog. Polym. Sci., vol. 32, no. 8-9, pp. 762-798, Aug. 2007.

[15] P. A. Gunatillake and R. Adhikari, "Biodegradable synthetic polymers for tissue engineering,” Eur. Cells Mater., vol. 5, pp. 1-16, Oct. 2003.

[16] W. Schuurman, V. Khristov, M. W. Pot, P. R. van Weeren, W. J. A Dhert, and J. Malda, "Bioprinting of hybrid tissue constructs with tailorable mechanical properties,” Biofabrication, vol. 3, no. 2, p. 
021001, Jun. 2011.

[17] K. I. Draget, O. Smidsrød, and G. Skjåk-Bræk, "Alginates from Algae," in Biopolymers Online, E. J. Vandamme, S. De Baets, and A. Steinbüchel, Eds. Weinheim, Germany: Wiley-VCH Verlag GmbH \& Co. KGaA, 2005.

[18] X.-H. Zhou, D.-X. Wei, H.-M. Ye, X. Zhang, X. Meng, and Q. Zhou, "Development of poly(vinyl alcohol) porous scaffold with high strength and well ciprofloxacin release efficiency,” Mater. Sci. Eng. C, vol. 67, pp. 326-335, Oct. 2016.

[19] A. A. Abbas, S. Y. Lee, L. Selvaratnam, N. Yusof, and Kamarul. T, "Porous PVA-Chitosan based hydrogel as an extracellular matrix scaffold for cartilage regeneration,” Eur. Cells Mater., vol. 16, no. Suppl. 2, 2008.

[20] A. Rasyida, "Preliminary study of alginates extracted from brown algae (Sargassum sp.) available in Madura Island as composite based hydrogel materials," 2016.

[21] E. F. dos Reis et al., "Synthesis and characterization of poly (vinyl alcohol) hydrogels and hybrids for rMPB70 protein adsorption," Mater. Res., vol. 9, no. 2, pp. 185-191, Jun. 2006.

[22] G. W. Brindley and G. Brown, Crystal structures of clay minerals and their X-ray identification. London: Mineralogical Society, 1980.
[23] E. A. P. Wibowo, "Sintesis komposit N-TIO2/Bentonit dan karakteriasi menggunakan FTIR,” JTT (Jurnal Teknol. Terpadu), vol. 5, no. 1, pp. 96-99, Apr. 2017.

[24] Q. Gao, Y. He, J. Fu, A. Liu, and L. Ma, "Coaxial nozzle-assisted 3D bioprinting with built-in microchannels for nutrients delivery," Biomaterials, vol. 61, pp. 203-215, Aug. 2015.

[25] N. A. Peppas, Y. Huang, M. Torres-Lugo, J. H. Ward, and J. Zhang, "Physicochemical foundations and structural design of hydrogels in medicine and biology,” Annu. Rev. Biomed. Eng., vol. 2, no. 1, pp. 929, Aug. 2000.

[26] D. J. McHugh, A guide to the seaweed industry. Rome: Food and Agricultural Organization of The United Nations, 2003.

[27] S.-C. Chen, Y.-C. Wu, F.-L. Mi, Y.-H. Lin, L.-C. Yu, and H.-W. Sung, "A novel pH-sensitive hydrogel composed of N,Ocarboxymethyl chitosan and alginate cross-linked by genipin for protein drug delivery,” J. Control. Release, vol. 96, no. 2, pp. 285300, Apr. 2004.

[28] K. B. Narayanan and S. S. Han, "Dual-crosslinked poly(vinyl alcohol)/sodium alginate/silver nanocomposite beads - A promising antimicrobial material,” Food Chem., vol. 234, pp. 103-110, Nov. 2017. 